
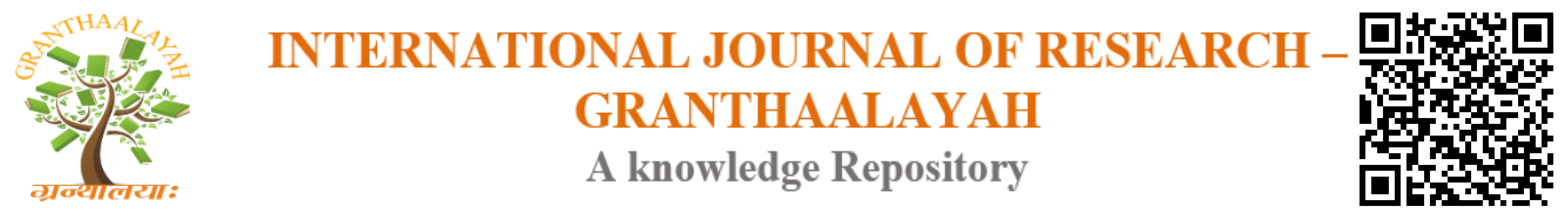

Social

\title{
STRATEGY TO PROMOTE RESEARCH SKILLS IN STUDENTS OF THE HEALTH AREA
}

\author{
Alida Vallejo Lopez ${ }^{1}$, Tibisay Beatriz Rincon Rios ${ }^{2}$, Franklin Gaston Arguello ${ }^{3}$ \\ ${ }^{1}$ MSC, Teacher University of Guayaquil \\ ${ }^{2}$ Ph.D., Teacher University of Zulia \\ ${ }^{3}$ Dr., Teacher University of Guayaquil
}

\begin{abstract}
In the new context of higher education; Research-based learning is a strategy used to understand and deepen knowledge during the educational process at all levels for the development of scientific evidence, considering that the best way to learn is experience. The objective of this article is to demonstrate the importance of implementing practical activities in the field of health to awaken the interest of students in research and development of scientific competencies. The methodology applied in the students of the health area, to promote the research in the development of the scientific capacities, was made a chronogram of visits to the departments of the ICBE; TPA and Embryology Laboratory, for the development of scientific tests by means of coherent practices or action schemes. In conclusion, when the student is actively involved in the teaching-learning process, he can develop skills for his professional performance. Promoting the interest of the student to investigate is undoubtedly an indispensable factor that must be fostered, analyzed and applied in the area of. Health Research is a process that requires adequate guidance and motivation to awaken, passion and dedication, which allows the development of scientific skills and competences.
\end{abstract}

Keywords: Research; Scientific Competences; Students; Health.

Cite This Article: Alida Vallejo Lopez, Tibisay Beatriz Rincon Rios, Franklin Gaston Arguello (2018). "STRATEGY TO PROMOTE RESEARCH SKILLS IN STUDENTS OF THE HEALTH AREA." International Journal of Research - Granthaalayah, 6(8), 189-195. https://doi.org/10.29121/granthaalayah.v6.i8.2018.1424.

\section{Introduction}

Education is a social process in which several elements participate, each of which fulfills a role to achieve the basic objective of preparing consciously and responsibly members of society, in order to provide committed citizens who provide knowledge, that benefits the humanity in the course of its history. Higher education institutions in Ecuador in recent years have seen the need to promote improvements in the educational process to optimize the academic performance of undergraduate students. 
From the redefinition of educational policies implemented by the Government of the Economist Rafael Correa Delgado in the last decade, a restructuring of the institutional scaffolding was generated to comply with the recommendations made by international organizations such as the World Bank and the Organization for Cooperation. and Economic Development (OECD, Santillana 2012).

In the new context of education; the teacher must promote the practice of research since the best way to learn is experience. Research-based learning is a strategy that serves to understand and deepen knowledge, on a general topic or a specific topic with in order to achieve a better learning, it must be promoted from the teaching to develop scientific competences.

Implementing models, strategies, techniques, methods, during the educational process is an initiative that must be supported and promoted by the Education authorities at all levels. Research scientific competence includes cognitive and social processes beyond the selection and processing of information or disciplinary knowledge, and has a more procedural nature by allowing the student to integrate in a creative and proactive way the knowledge in their critical interaction with respect to new situations and solve problems by constructing contextualized meanings. (Franco A 2 (2015): 231-252).

The objective of this article is to demonstrate the importance of implementing practical activities in the field of health to awaken the interest of students in researching and developing scientific competences.

Students who enter the health area participate in a complex process, of which only a quota is awarded, based on this evaluation process only students who obtain the highest scores will be admitted, this allows to recognize that their intellectual level It is one of the highest in the whole country. At its entrance they must complete a period of leveling, during which they are trained in subjects considered basic such as Language, Mathematics and Morphological Physiology, during this period of adaptation, students must adapt and be incorporated into the new system complying with the code and regulations of Higher Education Institutions.

In this process it is guaranteed that students with better coefficients and therefore those who have the potential to develop scientific skills and competences that would allow them to become great researchers enter the Faculty of Medical Sciences. To achieve this, we must start by working with them motivating them and promoting activities that raise interesting problems and that in turn contribute to achieve this goal.

Therefore, coherent action plans and practices should be structured, in which we interacted with other professionals in the area, holding talks and visits to laboratories, hospitals, Anatomy Workshops Institutes, where they are in direct contact with the medical field, in where they recognize and visualize with greater clarity their mission and responsibility when aspiring to be health professionals.

Formative research seeks the generation of knowledge by means of which the development of the ideologically critical and autonomous research culture is initiated in some way, which allows adhering to the advances of knowledge. (Maldonado, L. et al., 2007 p.46) 
Nobody today doubts the importance of sciences in training for work that is becoming increasingly complex and incorporates more and more science and technology. In a globalized society, the need to create, research and adopt technology is a shared truth, which presupposes, first of all, the appropriation of the scientific knowledge necessary to carry out this purpose.

The question that we are interested in answering here is: what science education best contributes to the development of the capacities that citizens deserve to meet? Or, what approach to science best shapes us as citizens? (Hernández, 2005).

The term motivation derives from the Latin movere (to move). The dictionary of the Applied Linguistic Electronic Magazine (RAEL) defines it in its third meaning as a preparatory mental test of an action to animate or animate to execute it with interest and diligence.

The latter perfectly defines the concept to which we refer in the educational context. More academically, Pintrich and Schunk (2006) define motivation as the process that directs us toward the goal or goal of an activity, which instigates and maintains it. Therefore, it is more a process than a product, implies the existence of some goals, requires certain activity (physical or mental), and is a determined and sustained activity (Mentioned by Boza - Toscano - 2012)

The mere fact of relating in some way with the scientific medical field, arouses even more the curiosity of the students and gives an added value to the fact of studying contents in the books.

In the Faculty of Medical Sciences of the University and Guayaquil, there are laboratories equipped to develop academic and scientific research activities, including the Embryology Laboratory, where students can observe tissue samples from the stage through electronic microscopes. embryonic during his stage of studies in the race, there is also a biology laboratory, also called the Institute of Basic Experimental Surgery and Simulation to simulate a problem situation in the health of a patient, in this case a simulator robot in both its breathing, heart beats, crises that could occur in reality with the visualization of a monitor with heart rate, respiratory data, among others, another very important department is the Anatomical Preparations Workshop, which allows students to observe and locate each anatomical part of a bone and including knowing the organs in their structure. It also has a well-organized team of teaching assistants who give support to that department in their work to socialize both the new techniques of preservation of the anatomical pieces and the information of all their material for a better understanding and better learning.

These resources, which are first level, are used only by the students in a single semester, being valuable resources whose use from my point of view must be optimized with access to all students throughout their career due to the great scientific value that contribute to knowledge

In the new century research has an important role in higher education, the research activity helps to understand the situation of a problem and the factors that intervene in it, it also allows students to develop skills and teachers to approach the knowledge of the the same way that scientists do.

Scientific competences are enhanced when teachers and students approach knowledge from the perspective of a research project where they interact with situations inherent to the scientific 
environment (decision-making, innovation, communication of results, among others). This type of strategy enhances the development of scientific competences and offers the student a much more significant horizon for his future professional life, while he realizes the profession and the teaching role

However, to achieve this goal: "We need to improve our strategies and policies for training, research, innovation, management and financing, eliminating ideological barriers and prejudices, taking advantage of successful experiences and the opportunities offered by new technologies" (Para Ignacio, 2012 page 24.)

\section{Material and Method}

A review of the literature of the Hinari, Medline and Latindex database was carried out, as well as related articles obtained from Scielo, Redalyc Google Scholar websites. The analysis of the found articles was carried out and the article was carried out based on the information obtained.

A visit schedule to the Embryology Laboratories was established with Dr. Martha Baquerizo, Institute of Experimental Basic Surgery (ICBES) with Dr. Ana María Viteri, and Anatomical Preparations Workshop whose Director and Dr. Rafael Cuello (TPA) in coordination with Area Directors and with the approval of Dr. Franklin Arguello Leveling Manager and the permission of Dr. Jorge Daher Nader Dean of the Faculty of Medical Sciences of the University of Guayaquil. In order to attend these places previously, instructions were given on biosecurity measures with the use of aprons, face masks and gloves, as well as on the subject of following the instructions of the trainer and respect and ethics.

Subsequently, the visit was made in the week 11 of the July 16 to July 20 ICBES and from July 30 to August 3 the visit to the embryology laboratory and the weeks of August 6 to 17 were the other visits to the that the students attended voluntarily of the 5 courses assigned in the semester of leveling.

\section{Results}

All the students who attended the visits were very interested in learning more and also took notes and made reports based on the experience and the material that was exposed and observed by each Department, they took pictures of the electronic microscopes and the samples of tissue through the eyepieces to identify in the report the samples of embryological tissue observed by them during the visits.

In the ICBES they were able to enter the surgical suite into a surgery room specially equipped to recreate the hospital environment, and they learned about the monitors that indicate the vital signs when they were in contact with the patients in this case with the simulator robots. They were very interested in knowing more closely the parts of the human body in the TPA that are very motivated and strengthened in their desire to belong to the Faculty of Medical Sciences, they stated that this type of activities is a complement to learning and that they are interested in knowing more deeply the topics that They exposed them. 
Pre-scheduled visits are a way to integrate initial students who have never had a relationship with the medical field, towards a new mentality in which their scientific curiosity is awakened, and they begin to ask more questions.

Later during the teacher-student interaction, the possibility of researching a topic that is of interest was raised, either because there is a health problem in your family or because you are always interested in a scientific topic related to health. During the process they are also given the indication of the structure that their research work should have, which they must understand little by little and deliver it at the end of their class period.

This type of activities gives the initial guidelines to start sowing a new generation of researchers who work on their own initiative to increase scientific production with a critical thinking aimed at improving the living conditions of society.

The author Ruiz Ramírez, J. (2010) in his work the importance of research considers. The research stimulates critical thinking, creativity and through it, that the learning process is vitalized and memorization is fought, which has contributed so much to forming passive professionals, few lovers of innovation, with little curiosity and personal initiative. Research is of vital importance in postgraduate studies, it is not possible to have high-level graduates if they are not investigated (Ruiz Ramírez, J. 2010).

In scientific research the student has to learn that this starts with a new idea, is structured as a hypothesis, which is accepted or rejected depending on the results and culminates with the publication of the results. There must be a profound transformation in the process of teaching science education, in terms of what should be taught, to whom and how it should be taught. They should think about new curricular proposals, a training of transforming science educators, and recognize that scientific education should expand its borders and build bridges between what happens in the classroom, with non-formal settings, science clubs, museums and science spaces (González A et al 2016).

In scientific research the student has to learn that this starts with a new idea, is structured as a hypothesis, which is accepted or rejected depending on the results and culminates with the publication of the results. There must be a profound transformation in the process of teaching science education, in terms of what should be taught, to whom and how it should be taught. They should think about new curricular proposals, a training of transforming science educators, and recognize that scientific education should expand its borders and build bridges between what happens in the classroom, with non-formal settings, science clubs, museums and science spaces (González A et al 2016).

It recognizes the strategic role of higher education, both in the generation of knowledge and technological innovations, as in the training of professionals capable of studying and contributing to the understanding and solution of environmental problems, it is necessary from the undergraduate to design and implement programs that favor the formation of skills for the productive development of research and innovation activities (Perdomo, \& Martínez (2010). 
Universities should promote the interest of researchers to communicate science, as well as promote the participation of citizens in the processes of knowledge management itself, its applications, scope, risks and uncertainties; for this, it must encourage the acquisition of new skills in the research staff that facilitate the exchange processes with diverse audiences. This is a challenge that we must assume with wisdom, understanding that the science that counts is the one that is told, not only to our academic peers, but also to the diverse publics that make up society. (Castle A) Under the model of teaching and learning by research, a definition for scientific competence is adopted, which refers to the possibility that we must have and manifest in order to pose interesting problems and to be able to solve them based on frameworks of knowledge and attitudes that materialize in practices or coherent action schemes of such knowledge, communicating the results coherently to the scientific community. García G: Ladino And 2004.

It is recommended that all possible resources be used to motivate students' interest in researching. This strategy should also give freedom to manifest the interests of the student in various subjects, giving priority to the topics that are of most interest to start a study.

\section{Conclusion}

When the student is actively involved in the teaching-learning process, he can develop skills that serve him in his professional performance. Promote the interest of the student to investigate and understand certain situations or processes that affect and intervene in the life and health of people, is undoubtedly an indispensable factor that must be encouraged, analyzed and applied in the area of. Health Research in students is a process that requires proper guidance and above all motivation to awaken curiosity, passion and dedication, which allows the development of scientific skills and competencies. Students must be motivated to develop research, giving greater support with the implementation of specialized laboratories in the development of research activities.

\section{Final Reflection}

The promotion of research in the area of health should be encouraged from the first stages of study, so that the future health professional develops scientific skills that allow him to assume his role in society with social and ethical responsibility to the culminate your professional career.

\section{References}

[1] Boza Carreño Ángel y Toscano Cruz María de la O 2012) Universidad de Huelva MOTIVOS, ACTITUDES Y ESTRATEGIAS DE APRENDIZAJE: APRENDIZAJE MOTIVADO EN ALUMNOS UNIVERSITARIOSVOL. 16, No 1 (enero-abril 2012) E-mail: aboza@uhu.es, maria.toscano@dedu.uhu.es http://www.ugr.es/local/recfpro/rev161ART8.pdf

[2] Castillo Vargas Andrés Dr. Importancia de la divulgación en la comunicación científica académica Instituto de Investigaciones Psicológicas Escuela de Psicología Universidad de Costa Rica http://www.ebci.ucr.ac.cr/sites/default/files/descargables/castillo_vargas_andres_importancia_de_ la_divulgacion_en_la_comunicacion_cientifica_academica.pdf

[3] Franco-Mariscal Antonio Joaquín ENSEÑANZA DE LAS CIENCIAS, NÚM. 33.2 (2015): 231$252 \mathrm{http} / / / \mathrm{dx}$.doi.org/10.5565/rev/ensciencias.1645 ISSN (impreso): 0212-4521 / ISSN (digital): 2174-6486 file:///C:/Users/uf/Downloads/293274-407229-1-PB\%20(1).pdf

[4] García Germán: Ladino Yolanda 2004 Desarrollo de competencias científicas a través de una estrategia de enseñanza y aprendizaje por investigación 
[5] https://www.researchgate.net/publication/277260057_Desarrollo_de_competencias_cientificas_a _traves_de_una_estrategia_de_ensenanza_y_aprendizaje_por_investigacion

[6] Gonzáles Argotea Javier, Alexis Alejandro García-Rivero By Alberto Juan Dorta-Contreras Articulo Original Producción Científica Estudiantil en Revistas Médicas Cubanas 1995-2014. Universidad Nacional Autónoma de México, Facultad de Medicina Disponible en Internet 2 de marzo de 2016 Inv Ed. Med.2016;5(19):155---163

file:///c:/Users/uf/Downloads/s2007505716000247 S300 es.pdf

[7] Nadi pone hoy en duda la importancia de las ciencias en la formación para un trabajo que se hace cada día más complejo e incorpora cada día más ciencia y tecnología. En la sociedad globalizada es una verdad compartida la necesidad de crear, investigar y adoptar tecnología, lo que supone, antes que todo, la apropiación del conocimiento científico necesario para realizar este propósito. La pregunta que nos interesa responder aquí es: ¿qué formación en ciencias contribuye mejor al desarrollo de las capacidades que es deseable que reúnan los ciudadanos?, o bien, ¿qué aproximación a las ciencias nos forma mejor como ciudadanos? (Hernández. 2005).

[8] Maldonado, L. et al. (2007). Visibilidad y formación en investigación. Estrategias para el desarrollo de competencias investigativas. Studiositas, 2 (2), 43-56 file://C:/Users/hp/Downloads/DialnetVisibilidadYFormacionEnInvestigacion-2719652.pdf

[9] OECD SANTILLANA AUTOR VOLUMEN 2 EDICION ESPAÑOLA 2012 Informe PISA 2009: 2011 Superación del entorno social Equidad en las oportunidades y resultados del aprendizaje (Volumen II) https://www.mecd.gob.es/dctm/ievaluacion/internacional/pisa-2009-conescudo.pdf?documentId=0901e72b808ee4fd

[10] Ignacio Para Rodríguez-Santana El Modelo de Futuro de Gestión de la Salud, Propuestas Para Un Debate Editorial Visión Libros, 2012 https://books.google.co.ve/books/about/El_Modelo_de_Futuro_de_Gesti\%C3\%B3n_de_la_Sa.ht $\mathrm{ml}$ ?id=_PPczb7qiagC\&redir_esc $=\mathrm{y}$

[11] Pérez-Reveles, M., \& Topete-Barrera, C., \& Rodríguez-Salazar, L. (2014). MODELO PARA LA FORMACIÓN Y EL FORTALECIMIENTO DE INVESTIGADORES EN LAS UNIVERSIDADES. Investigación Administrativa, (114), 82-94. http://www.redalyc.org/pdf/4560/456044957005.pdf

[12] Ruiz Ramírez, Jorge Importancia de la investigación Revista Científica, vol. XX, núm. 2, marzoabril, 2010, pp. 125-126 Universidad del Zulia Maracaibo, Venezuela recuperado de Ruiz Ramírez, J. (2010). Importancia de la investigación. Revista Científica, XX (2), 125-126. http://www.redalyc.org/pdf/959/95912322001.pdf

\footnotetext{
*Corresponding author.

E-mail address: alida.vallejol@ug.edu.ec/ demfmluz@gmail.com/ franklin.arguelloa@ug.edu.ec
} 